Supplement of Atmos. Chem. Phys., 18, 9879-9896, 2018

https://doi.org/10.5194/acp-18-9879-2018-supplement

(C) Author(s) 2018. This work is distributed under

the Creative Commons Attribution 4.0 License.

(c) (1)

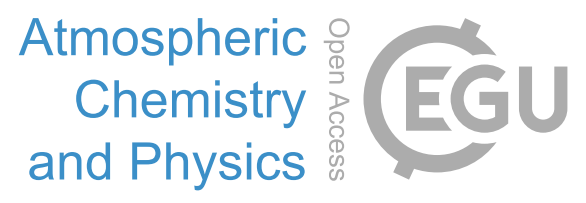

Supplement of

\title{
Amplification of light absorption of black carbon associated with air pollution
}

Yuxuan Zhang et al.

Correspondence to: Qiang Zhang (qiangzhang@tsinghua.edu.cn)

The copyright of individual parts of the supplement might differ from the CC BY 4.0 License. 


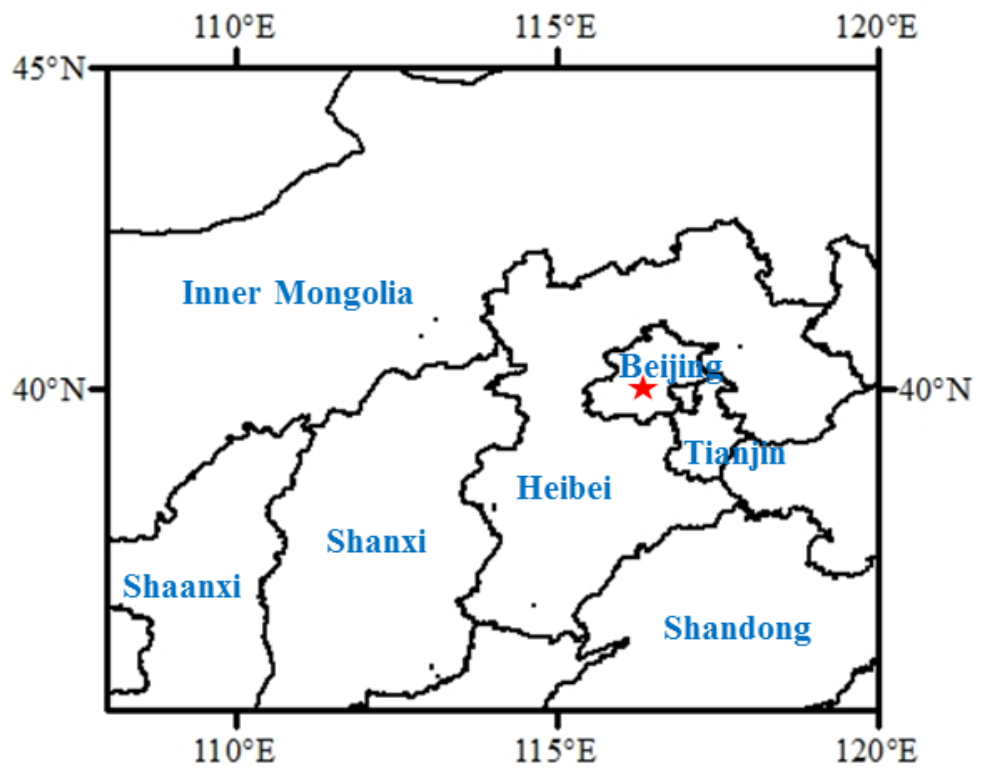

2 Figure S1. Location of the observation site (red star).

3 Figure S1 shows the geographic location of our observation site (namely red star 4 marked in the Fig. S4). The site $\left(40^{\circ} 00^{\prime} 17^{\prime \prime} \mathrm{N}, 116^{\circ} 19^{\prime} 34^{\prime \prime} \mathrm{E}\right)$ is located in megacity 5 Beijing, the capital of China. The air pollution levels in our site can be influence by 6 the air mass from adjacent regions (i.e., Tianjin, Heibei, Inner Mongolia, Shanxi, 7 Shandong). 

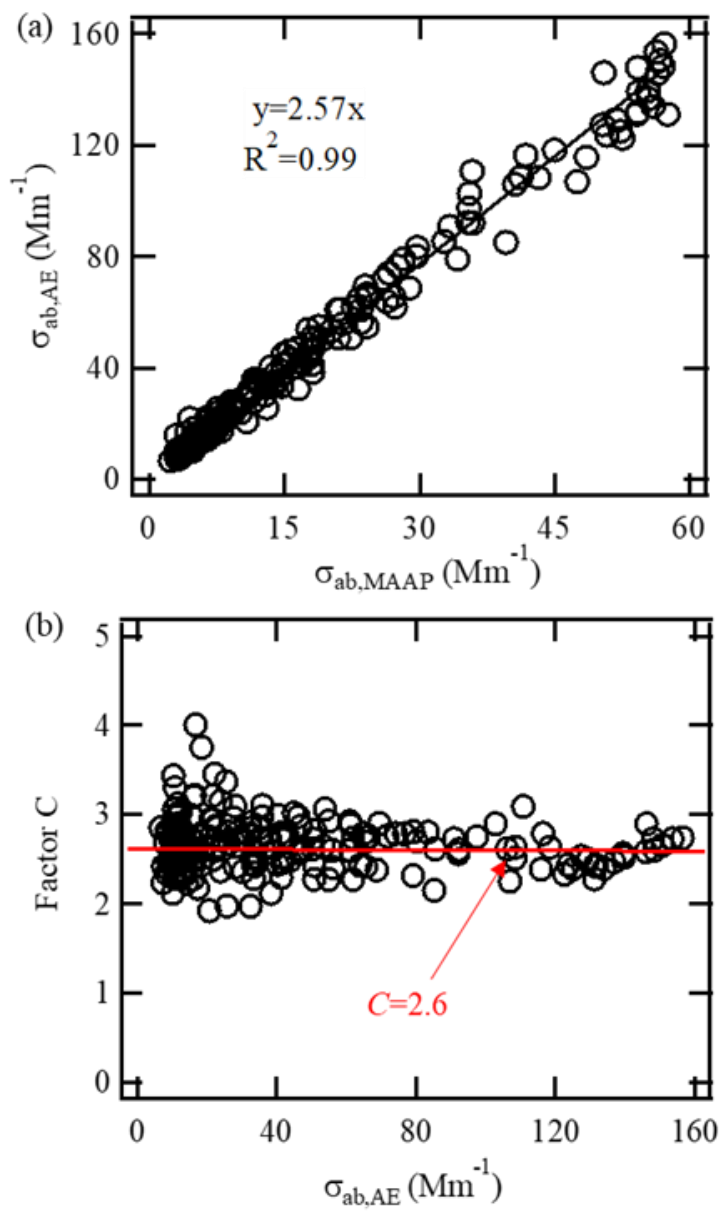

Figure S2. (a) The correlation between the absorption coefficient from AE33 at 660 $\mathrm{nm}\left(\sigma_{\mathrm{ab}, \mathrm{AE}}\right)$ and MAAP at $670 \mathrm{~nm}\left(\sigma_{\mathrm{ab}, \mathrm{MAAP}}\right) .(\mathrm{b})$ Variety of multiple-scattering compensation factor $C$ with different Aethalometer measurements.

Aethalometer artefacts are mainly from the loading effect and multiple-scattering effect (Weingartner et al., 2003; Segura et al., 2014). In terms of the loading effect, the compensation algorithm has been incorporated into Aethalometer model AE33 (Drinovec et al., 2015). In this study, we focused on the multiple-scattering compensation, which was characterized by enhancement parameter $C$. The factor $C$ for our sites was determined by comparing the absorption coefficient derived from $\operatorname{AE} 33\left(\sigma_{\mathrm{ab}, \mathrm{AE}}\right)$ with the ones from MAAP $\left(\sigma_{\mathrm{ab}, \mathrm{MAAP}}\right)$. Noted that the AE33 and MAAP measurements used to calculate the factor $C$ were at different wavelengths, namely $660 \mathrm{~nm}$ and $670 \mathrm{~nm}$, respectively. Considering that the absorption is inversely proportional to wavelength (Bond and Bergstrom, 2006), the difference in wavelength would lead to an uncertainty of $\sim 1.5 \%$ for the corrected absorption coefficients in AE 
measurement. As shown in Fig. S2a, the slope 2.6 was taken as the value of factor $C$ to compensate the Aethalometer data. The specifically site-calculated values of the factor $C$ varies in the range of 1.9-4 in this work (Fig. S2b), consistent with previous studies (Drinovec et al., 2015; Weingartner et al., 2003; Segura et al., 2014). In this study, the uncertainty in the factor $C$ was dominated by the uncertainty in MAAP measurements. We corrected the MAAP data using the algorithm reported by Hyvärinen et al. (2013). They estimated that the uncertainty in absorption coefficients derived from MAAP based on the developed algorithm was $\sim 15 \%$ by comparing the results from a PAS against those derived from the MAAP in Beijing. This indicated that the factor $C$ used in our study ( 2.6) would exhibit an uncertainty of $\sim 15 \%$ from the uncertainty in MAAP measurements. Considering the uncertainty on the AE33 measurements was mainly from the factor $C$, the absorption coefficient from AE33 was estimated to have an uncertainty of $\sim 15 \%$.

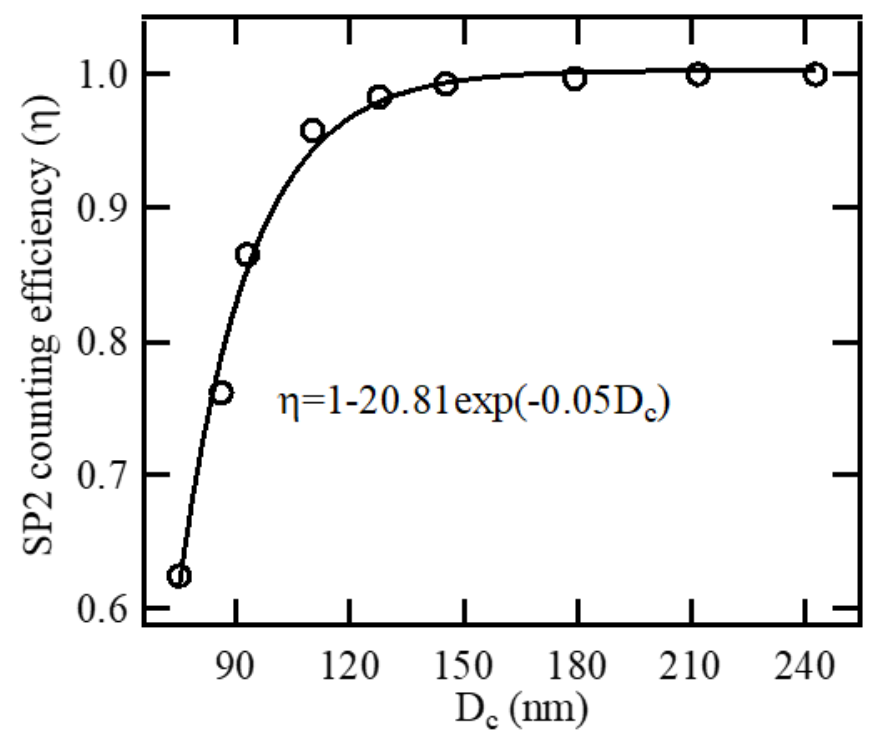

Figure S3. SP2 detection efficiency of particle $(\eta)$ in each rBC size-bin.

Figure S3 shows the SP2 detection efficiency concentration $(\eta)$ in each $\mathrm{rBC}$ size-bin. In our study, the SP2 detection efficiency was determined with a DMA-SP2/CPC system. Monodispersed Aquadag particles generated by DMA were simultaneously measured by SP2 and CPC. The size-resolved $\eta$ was calculated by dividing the particle number concentration from SP2 measurement by that from CPC measurement. The SP2 detection efficiency (Fig. S3) have been considered in the 


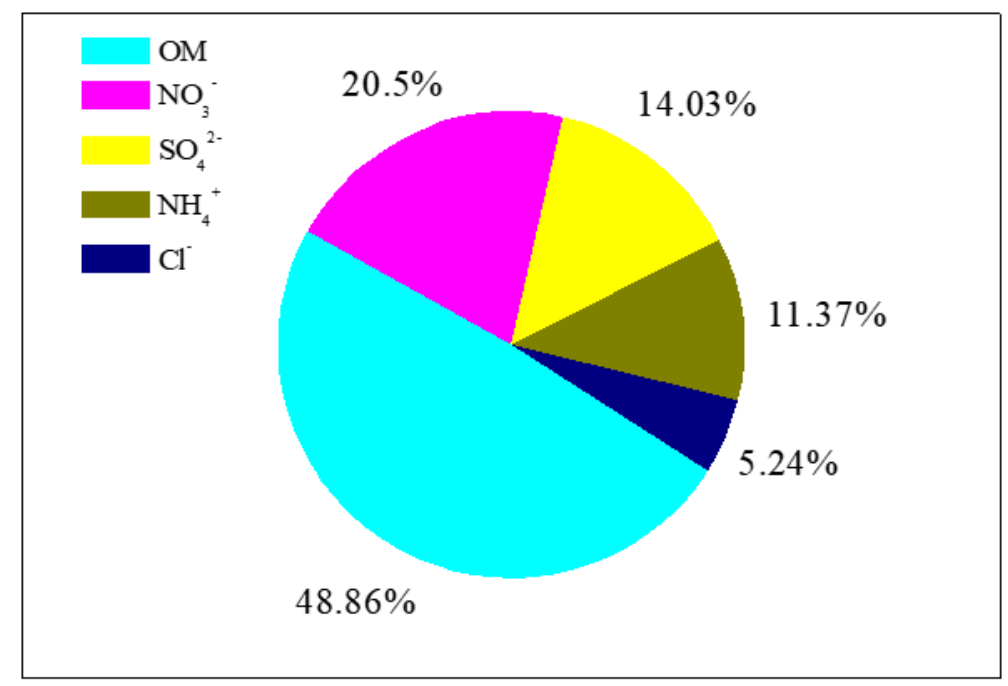

2

Figure. S4. Non-refractory compositions of $\mathrm{PM}_{1}$ particles during the campaign period.

The $R I_{\mathrm{s}}$ value used in this study are 1.50-0i based on the chemical compositions of coating materials during the campaign period. The components of coating materials was similar to non-refractory compositions in $\mathrm{PM}_{1}$ particles (Peng et al., 2016). Figure $\mathrm{S} 4$ reveals that the fraction of inorganic and organic components in coating materials of BC-containing particles are $\sim 51 \%$ and $\sim 49 \%$, respectively. It is known from the literature (Schkolnik et al., 2007; Mallet et al., 2003; Marley et al., 2001) that major inorganic components of ambient aerosol from urban emission (nitrate, sulfate, mineral dust, sea salt and trace metal) have a refractory of (1.5-1.6)-0i and there is a range of (1.4-1.5)-0i for the refractory of organic components. In this study, we used the values of $1.55-0 \mathrm{i}$ and $1.45-0 \mathrm{i}$ as refractive indexes of inorganic and organic components of coating materials. The refractive index of a mixture particle can be calculated as the volume weighted average of the refractive indices of all components (Hänel, et al. 1968; Marley et al., 2001; Bond and Bergstrom, 2006; Schkolnik et al., 2007), as $\widetilde{\mathrm{m}}=\sum_{\mathrm{i}} \widetilde{\mathrm{m}}_{\mathrm{i}} \mathrm{c}_{\mathrm{i}}$, where $\widetilde{\mathrm{m}}$ is the refractive index of a mixture particle; $\widetilde{\mathrm{m}}_{\mathrm{i}}$ is the refractive index of particle species; $\mathrm{c}$ is the volume ratio of particle species. Based on the equation, the refractive index of coating materials of $\mathrm{BC}$-containing particles $\left(R I_{\mathrm{S}}\right)$ was $\sim 1.50-0 \mathrm{i}$ during the campaign period. 


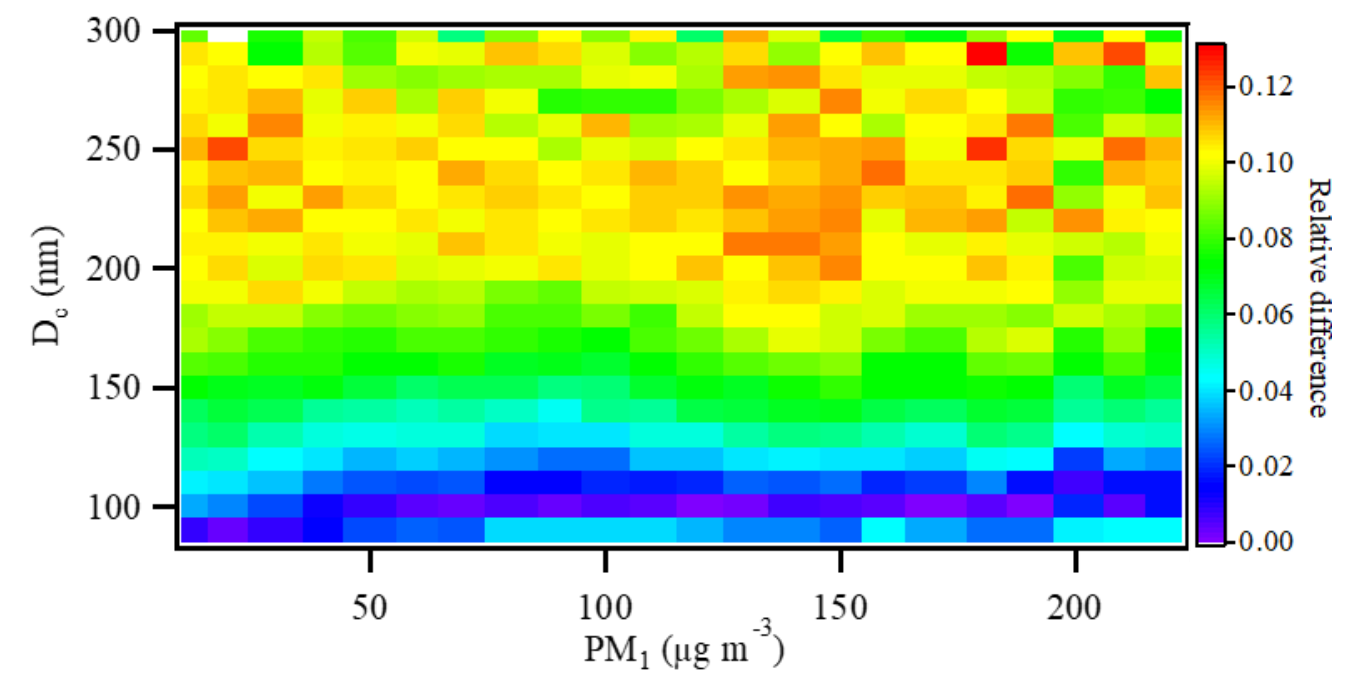

2 Figure S5. The relative difference between the sizes of BC-containing particles $\left(D_{\mathrm{p}}\right)$

3 derived from Mie calculation with $R I_{\mathrm{c}}$ of 2.26-1.26i and 1.95-0.79i.

$4 \quad$ Various values (e.g., 2.26-1.26i, 1.95-0.79i) of refractive index of $\mathrm{BC}$ core $\left(R I_{\mathrm{c}}\right)$

5 have be used in literature (Bond and Bergstrom, 2006; Cappa et al., 2012; Taylor et al.,

6 2015). Figure S5 shows the relative difference between the sizes of BC-containing

7 particles $\left(D_{\mathrm{p}}\right)$ derived from Mie calculation with $R I_{\mathrm{c}}$ of 2.26-1.26i and 1.95-0.79i. For

8 BC-containing particles with $75-300 \mathrm{~nm} \mathrm{rBC}$ cores, the relative difference is $3-10 \%$,

9 indicating that the $D_{\mathrm{p}}$ values were not sensitive to $R I_{\mathrm{c}}$ values in our study. This could

10 be attributed to significantly larger in volume of coating materials than that of $\mathrm{rBC}$ 11 cores. 


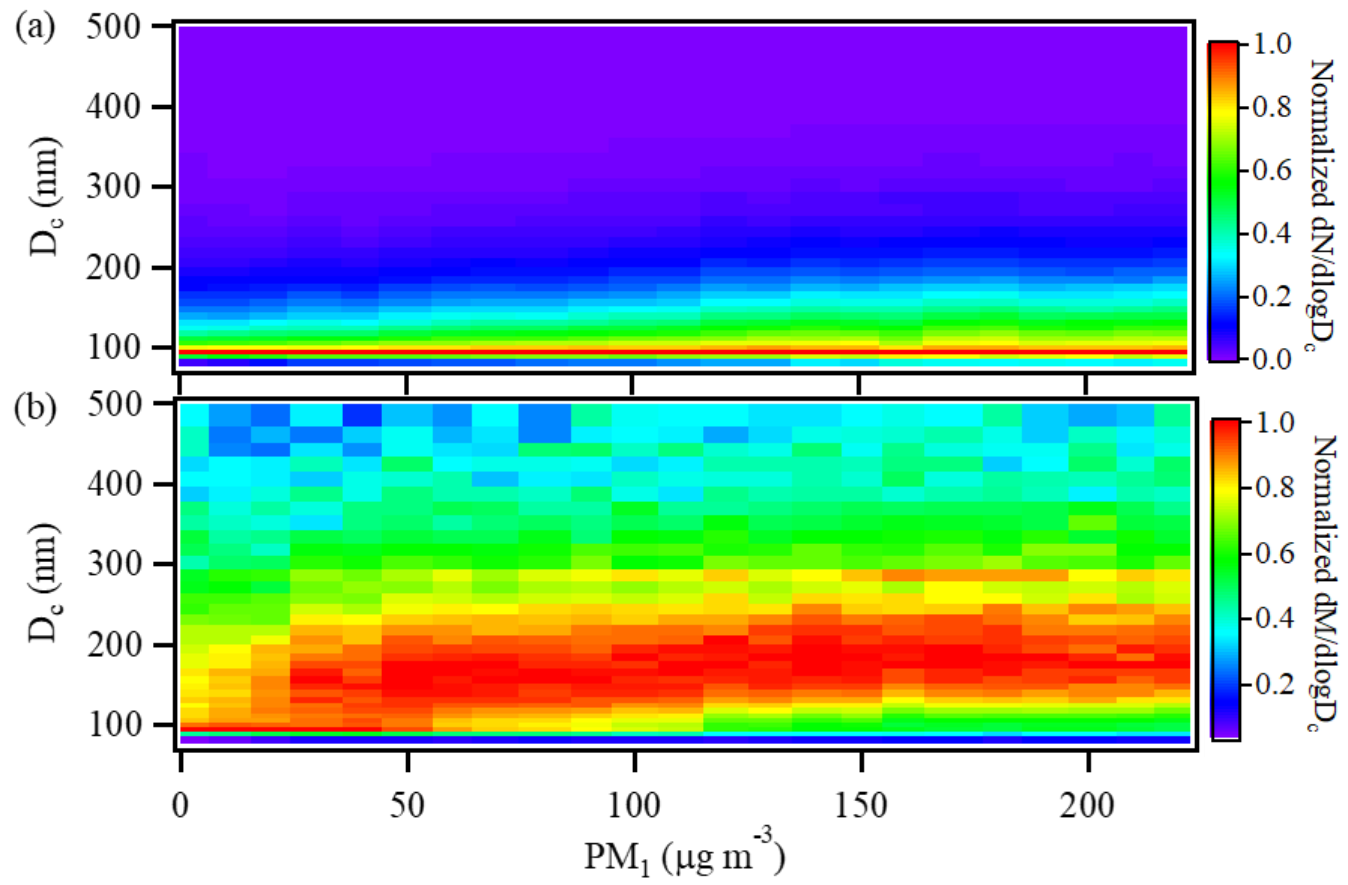

Figure S6. Size distribution of refractory $\mathrm{BC}(\mathrm{rBC})$ as a function of the $\mathrm{PM}_{1}$ concentration: (a) number size distribution and (b) mass size distribution.

Figure $\mathrm{S} 6$ shows the size distribution of $\mathrm{rBC}$ as a function of the $\mathrm{PM}_{1}$ concentration. Above the detection limit of SP2 incandescence ( $\mathrm{rBC}$ with size larger than $\sim 75 \mathrm{~nm}$ ), the number size distribution of $\mathrm{rBC}$ cores shows a peak at $\sim 95 \mathrm{~nm}$ under different $\mathrm{PM}_{1}$ concentration (Fig. S6 (a)), and there are about 95\% of rBC particles in number concentration lower than $200 \mathrm{~nm}$. As shown in Fig. S6 (b)), the mass size distribution of $\mathrm{rBC}$ cores shows a wide mode at $295-200 \mathrm{~nm}$ under different PM concentration. 


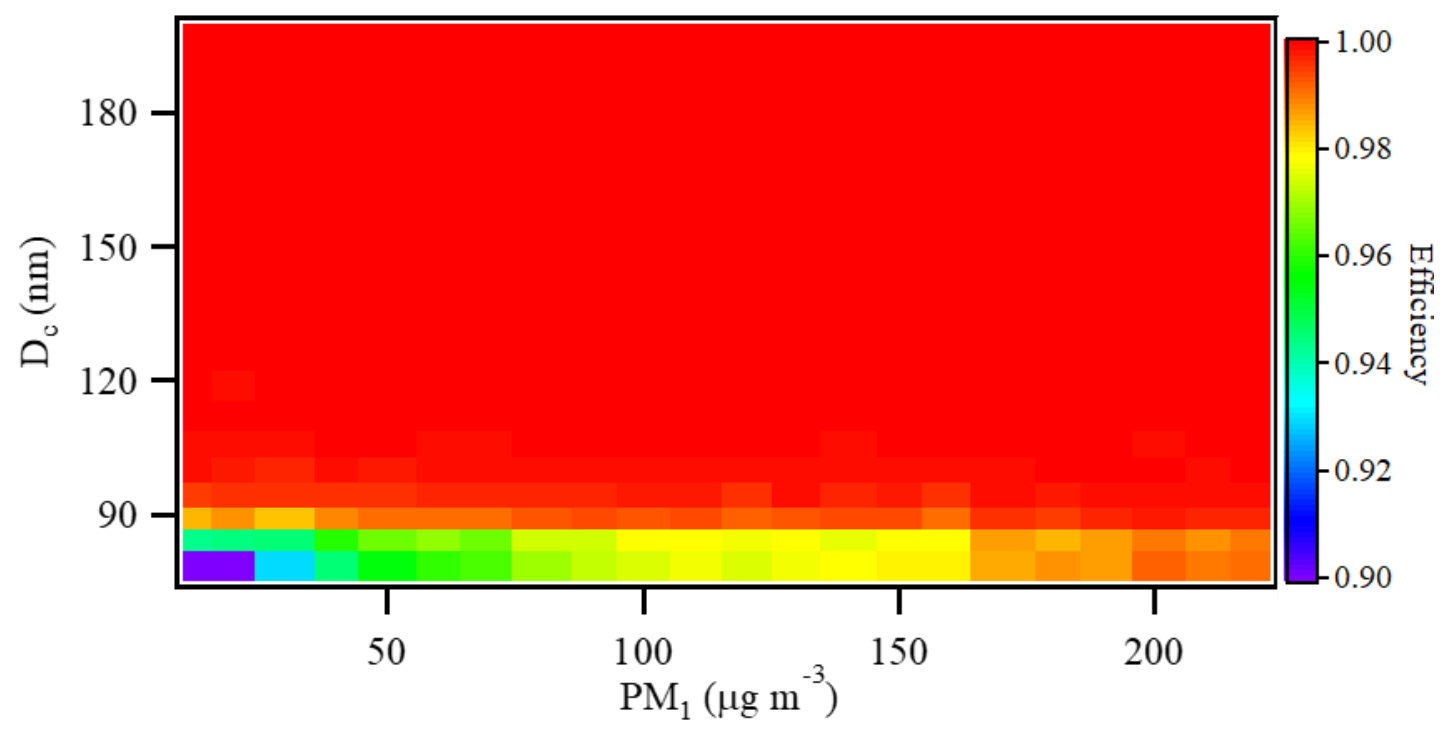

1

2 Figure S7. The detect efficiency of SP2 scattering for BC-containing particles with

3 size-resolved $\mathrm{rBC}$ cores $(75-200 \mathrm{~nm})$ under different $\mathrm{PM}_{1}$ concentration. In this study,

4 the detect efficiency of SP2 scattering in terms of BC-containing particles at a certain

$5 \mathrm{rBC}$ core size is defined as the ratio of the number concentration of particles above the

6 detection limit of SP2 scattering and total particles.

7

Figure S7 shows the detect efficiency of SP2 scattering for BC-containing particles with size-resolved $\mathrm{rBC}$ cores $(75-200 \mathrm{~nm})$ under different $\mathrm{PM}_{1}$ concentration. For BC-containing particles above the detection limit of our SP2 incandescence (rBC cores larger than $\sim 75 \mathrm{~nm}$ ), the detect efficiency of SP2 scattering is defined as the ratio of the number concentration of particles above the detection limit of SP2 scattering and total particles. The SP2 scattering exhibited a high detection efficiency (90-100\%) for observed BC-containing particles with $\mathrm{rBC}$ cores more than $75 \mathrm{~nm}$, which could be attributed to large BC-containing particles $(\sim 180-500 \mathrm{~nm}$ shown in Fig. S8) in our site due to atmospheric aging. High detection efficiency of SP2 scattering is favor to retrieve the thickness of coating materials on $\mathrm{rBC}$ cores $(>75 \mathrm{~nm}$ size studied in this work) based on scattering signal. 


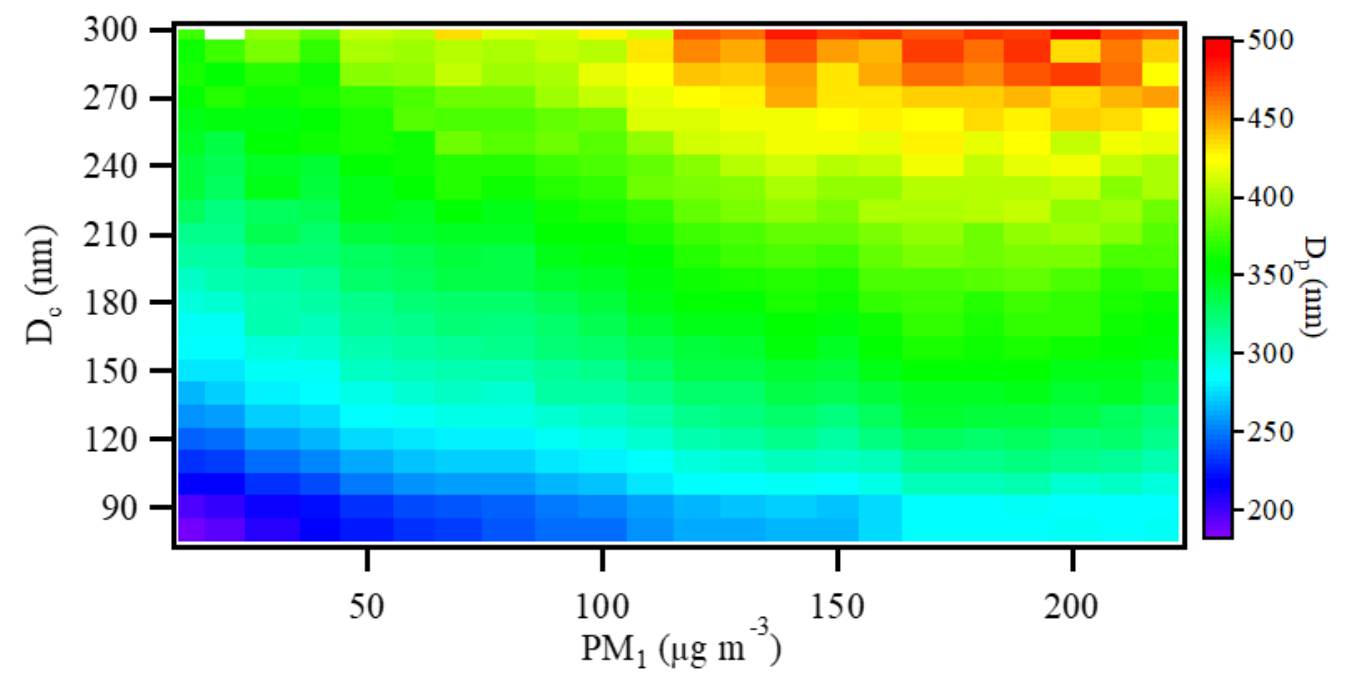

1

2 Figure S8. Frequency of the $D_{\mathrm{p}} / D_{\mathrm{c}}$ ratio of $\mathrm{BC}$-containing particles with size-resolved $3 \mathrm{rBC}$ cores as a function of PM1 concentrations.

Figure $\mathrm{S} 8$ shows frequency distribution of the $D_{\mathrm{p}} / D_{\mathrm{c}}$ ratio of $\mathrm{BC}$-containing particles with size-resolved $\mathrm{rBC}$ cores under different $\mathrm{PM}_{1}$ concentrations. For BC-containing particles with 75-300 $\mathrm{nm} \mathrm{rBC}$ cores, their particle size was in the range of $180-500 \mathrm{~nm}$. The particle size $\left(D_{\mathrm{p}}\right)$ of BC-containing particles with $\mathrm{rBC}$ cores at a certain size significantly increased with increasing $\mathrm{PM}_{1}$ concentration, revealing more coating materials on $\mathrm{BC}$ surface under more polluted environment.

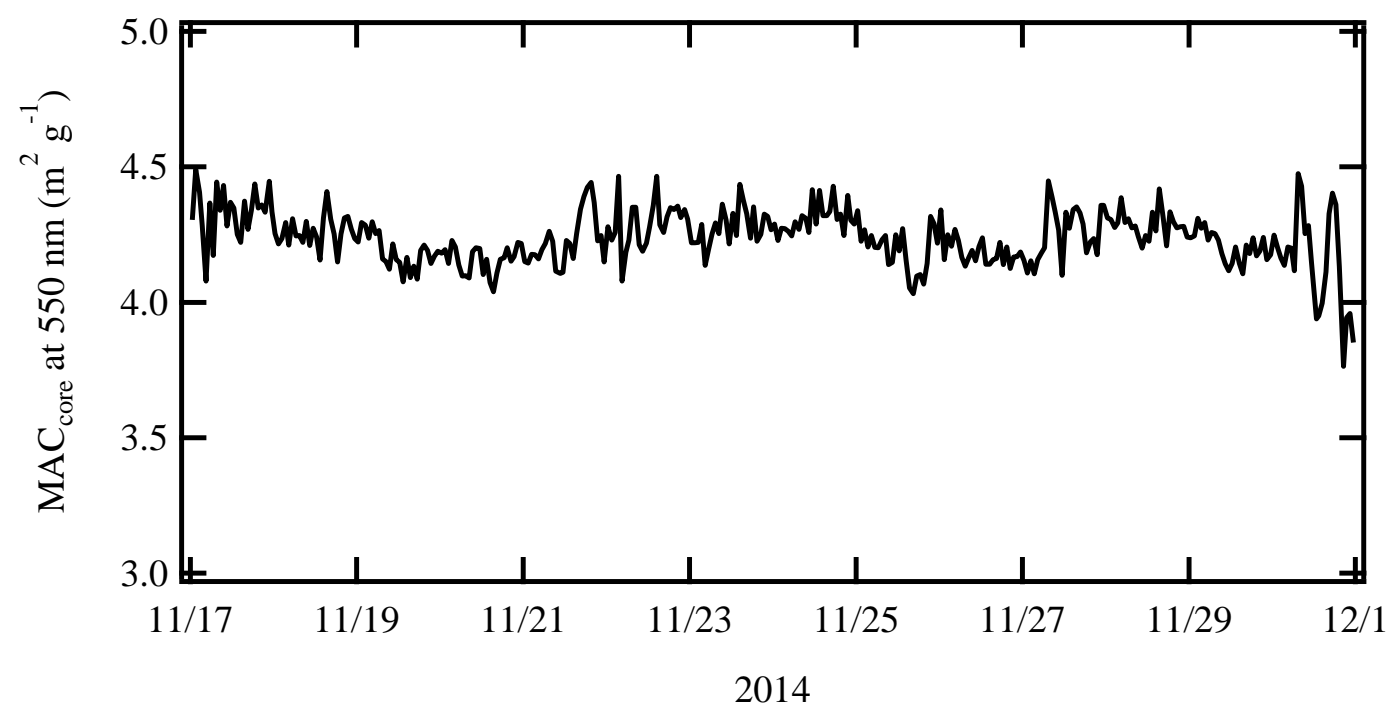

Figure. S9. The time series of MAC derived from Mie calculation for BC cores (i.e., bare $\mathrm{BC})$ at $880 \mathrm{~nm}$.

In this study, we used Mie mode to calculate optical properties of all 
1 BC-containing particles including bare $\mathrm{BC}$ and aged BC. Note that Mie theory is

2 fundamentally ill-suited to calculation of optical properties for bare BC particles,

3 which would lead to an uncertainty of their light absorption. Based on Mie calculation,

4 we obtained the $M A C$ of $\mathrm{rBC}$ core $\left(M A C_{\mathrm{c}}\right)$ at $880 \mathrm{~nm}$ in the range of 3.8-4.5 $\mathrm{m}^{2} / \mathrm{g}$ with

5 an average of $\sim 4.3 \mathrm{~m}^{2} / \mathrm{g}$ during the campaign period (Fig. S9). Bond and Bergstrom

6 (2006) suggested a value of $7.5 \mathrm{~m}^{2} / \mathrm{g}$ for the MAC of bare BC at $550 \mathrm{~nm}$. Considering

7 that the absorption is inversely proportional to wavelength (Bond and Bergstrom,

8 2006), the MAC of bare $\mathrm{rBC}$ at $880 \mathrm{~nm}$ is estimated to be $\sim 4.7 \mathrm{~m}^{2} / \mathrm{g}$, which was

9 slightly greater than that $\left(\sim 4.3 \mathrm{~m}^{2} / \mathrm{g}\right)$ obtained from Mie calculation in our study. This

10 indicated the uncertainty of MAC for bare $\mathrm{rBC}$ from Mie calculation was $\sim 8 \%$. We

11 estimated that the uncertainties of calculated BC light absorption related to MAC of

12 bare $\mathrm{rBC}$ from Mie calculation was $\sim 8 \%$.
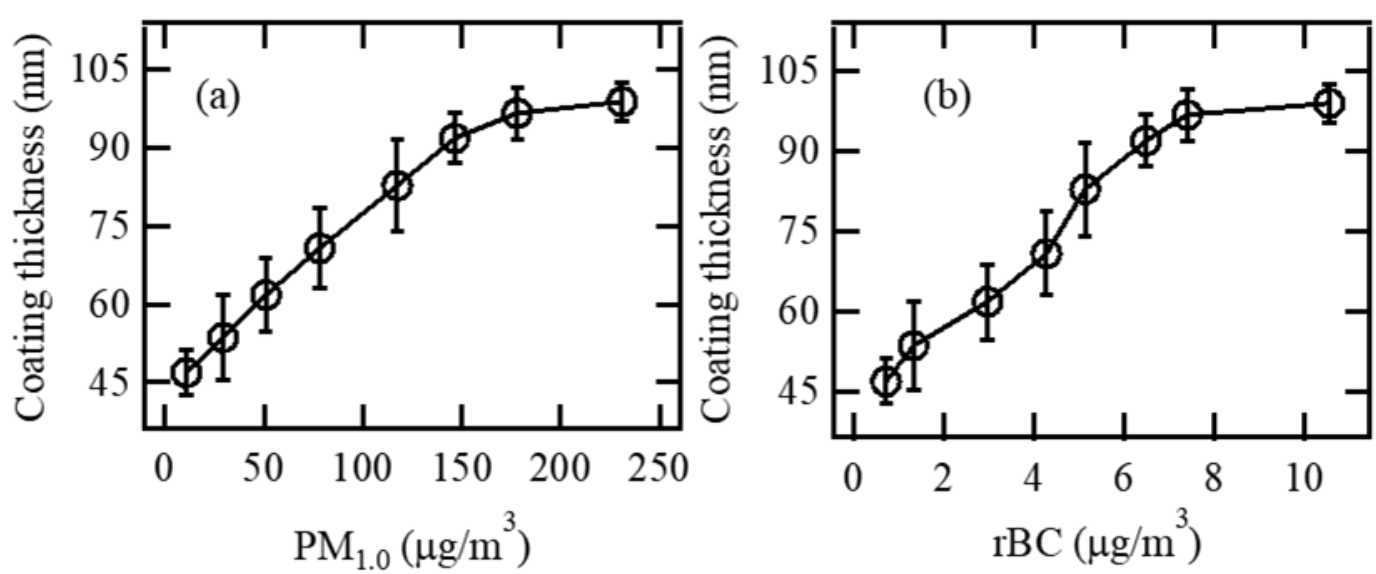

Figure S10. Variations in the coating thickness of BC-containing particles with the (a) $\mathrm{PM}_{1}$ and (b) $\mathrm{rBC}$ mass concentrations.

Figure S10 shows the coating thickness of BC-containing particles increased with $\mathrm{PM}_{1}$ and $\mathrm{rBC}$ concentration. The simultaneous increase in the $\mathrm{rBC}$ mass concentration and the amount of coating materials on the BC surface could significantly enhance the light absorption of BC-containing particles. 


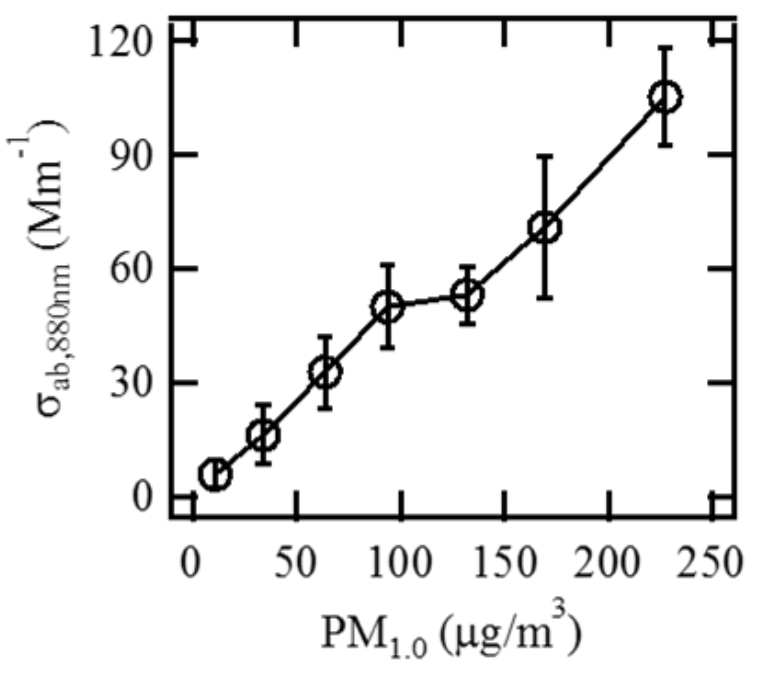

2 Figure S11. Changes of the light absorption coefficient at $880 \mathrm{~nm}\left(\sigma_{\mathrm{ab}, 880 \mathrm{~nm}}\right)$ with $\mathrm{PM}_{1}$

3 mass concentrations.

$4 \quad$ Figure S11 shows the changes of the light absorption coefficient at $880 \mathrm{~nm}$ $5\left(\sigma_{\mathrm{ab}, 880 \mathrm{~nm}}\right)$ with $\mathrm{PM}_{1}$ mass concentrations. The $\sigma_{\mathrm{ab}, 880 \mathrm{~nm}}$ and $\mathrm{rBC}$ mass concentrations 6 increased with increasing $\mathrm{PM}_{1}$ mass concentrations. The simultaneous increase in the $7 \mathrm{rBC}$ mass concentration and the amount of coating materials shown in Fig. S10 8 revealed that the increase of $\sigma_{\mathrm{ab}, 880 \mathrm{~nm}}\left(\sim 18\right.$ fold from $\sim 10 \mu \mathrm{g} \mathrm{m}^{-3}$ of $\mathrm{PM}_{1}$ to $\sim 230 \mu \mathrm{g}$ $9 \mathrm{~m}^{-3}$ of $\left.\mathrm{PM}_{1}\right)$ could be attributed to simultaneous increase in the $\mathrm{rBC}$ mass 10 concentration and the amount of coating materials on the $\mathrm{BC}$ surface. 

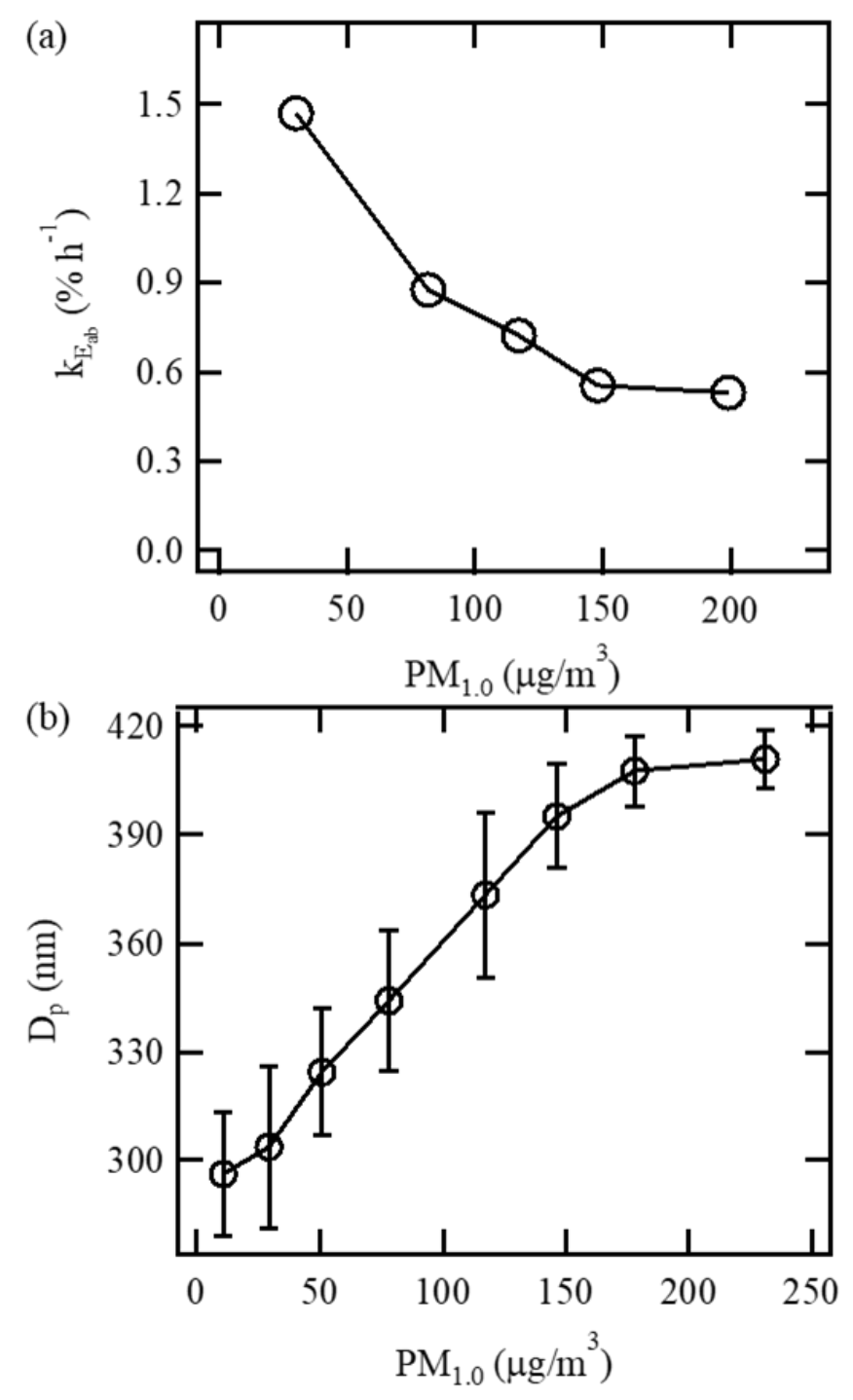

2 Figure S12. (a) Changes of growth rate of calculated $E_{\mathrm{ab}}\left(k_{\mathrm{Eab}}\right)$ with $\mathrm{PM}_{1}$ mass

3 concentration. (b) Variations in the diameter of BC-containing particles $\left(D_{\mathrm{p}}\right)$ with the 4 normalized $\mathrm{PM}_{1}$ concentrations.

5 As shown in Figure S12, the changes of growth rate of $E_{\mathrm{ab}}\left(k_{\mathrm{Eab}}\right)$ decreased with 6 increasing $\mathrm{PM}_{1}$ mass concentration. During the campaign period, the $k_{\text {Eab }}$ of 7 BC-containing particles was in the $0.5-1.5 \% \mathrm{~h}^{-1}$. The decrease of $k_{\text {Eab }}$ associated with 8 air pollution indicated the enhancement of light absorption capability of 9 BC-containing particles slowed with further air pollution, because $\mathrm{BC}$ aging process by condensational growth was less effective for more-aged BC particles with larger

11 size under more pollution environment (Fig. S12b). The net change in diameter for a 12 given amount of material deposited decreases with increasing particle size due to 13 surface-to-volume scaling, which would expect the growth rate of particles to 
1 decrease with increasing $\mathrm{PM}_{1}$ concentration and thus the $k_{\text {Eab }}$ would also decrease.

3 Figure S13. Correlation between the growth rate of $E_{\mathrm{ab}}\left(k_{\mathrm{Eab}}\right)$ and the growth rates of

$4 \quad \mathrm{rBC}$ mass concentrations $\left(k_{\mathrm{rBC}}\right)$ during the campaign period.

5 values were taken from Bond et al. (2013).

Figure S13 shows the the relationship between the change rate of calculated $E_{\mathrm{ab}}$ $\left(k_{\mathrm{Eab}}\right)$ and the change rates of $\mathrm{rBC}$ mass concentrations $\left(k_{\mathrm{rBC}}\right)$ with pollution development. Linear relationships were estimated, i.e., $k_{\mathrm{Eab}} \approx 0.027 k_{\mathrm{rBC}}$. Compared with the values of $k_{\mathrm{rBC}}$, the significantly smaller $k_{\mathrm{Eab}}$ value indicated that the light absorption capability of $\mathrm{BC}$ increased more slowly than $\mathrm{rBC}$ mass concentrations.

Table S1 The DRF of externally mixed BC from global climate models. The modeled

\begin{tabular}{ccccc}
\hline $\begin{array}{c}\text { Global climate } \\
\text { Model }\end{array}$ & $\begin{array}{c}\text { Mixing } \\
\text { state }\end{array}$ & $\begin{array}{c}\text { Modeled MAC } \\
\left(\mathrm{m}^{2} \mathrm{~g}^{-1}\right)\end{array}$ & $\begin{array}{c}\text { Modeled DRF } \\
\left(\mathrm{W} \mathrm{m}^{-2}\right)\end{array}$ & Reference \\
\hline $\begin{array}{c}\text { AeroCom models } \\
\text { GISS }\end{array}$ & External & 8.4 & 0.22 & Schulz et al. (2006) \\
LOA & External & 8.0 & 0.32 & Schulz et al. (2006) \\
LSCE & External & 4.4 & 0.30 & Schulz et al. (2006) \\
SPRINTARS & External & 9.8 & 0.32 & Schulz et al. (2006) \\
UIO-CTM & External & 7.2 & 0.22 & Schulz et al. (2006) \\
UMI & External & 6.8 & 0.25 & Schulz et al. (2006) \\
Other models & & & & Zhang et al. (2012) \\
BCC_AGCM & External & 4.3 & 0.10 & Kim et al. (2008) \\
CAM3 ECA & External & 10.6 & 0.57 & Chung and Seinfeld \\
GISS-GCM II & External & 7.8 & 0.51 & (2002) \\
Average values & & 7.5 & 0.31 & \\
\hline
\end{tabular}
$\mathrm{y}=0.027 \mathrm{x}$ $\mathrm{R}^{2}=0.21$ $\begin{array}{lllllll}-50 & 0 & 50 & 100 & 150 & 200 & 250\end{array}$ $\mathrm{k}_{\mathrm{rBC}}\left(\% \mathrm{~h}^{-1}\right)$ 
1 obtained by scaling the average DRF $\left(0.31 \mathrm{~W} \mathrm{~m}^{-2}\right)$ of externally mixed BC from 2 various climate models (Bond et al. 2013) with a scaling factor of the calculated $E_{\mathrm{ab}}$ 3 under different $\mathrm{PM}_{1}$ concentrations (Fig. 2b). The DRF $\left(0.31 \mathrm{~W} \mathrm{~m}^{-2}\right)$ of externally 4 mixed $\mathrm{BC}$ was the global averages from the global climate models listed in Table S1. 5 In order to point out the effect of BC light-absorption capability on DRF under 6 different $\mathrm{PM}_{1}$ concentrations, we did not consider the changes of $\mathrm{BC}$ amount for DRF 7 calculation. 
Table S2. Previous studies on the $\mathrm{BC}$ and $\mathrm{PM}\left(\mathrm{PM}_{1}\right.$ or $\left.\mathrm{PM}_{2.5}\right)$ mass concentrations in China.

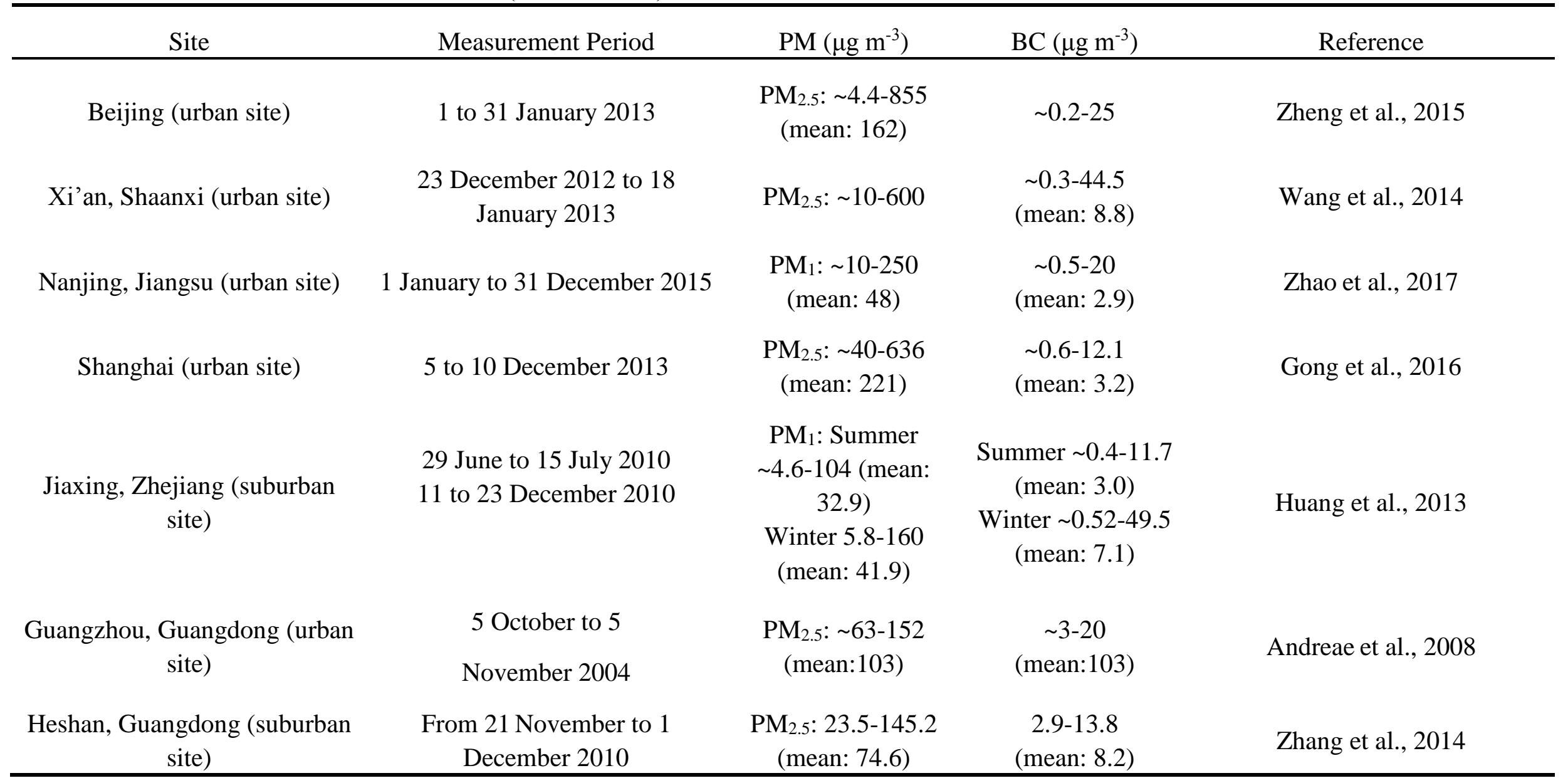


Table S2 lists the $\mathrm{BC}$ and $\mathrm{PM}\left(\mathrm{PM}_{1}\right.$ or $\left.\mathrm{PM}_{2.5}\right)$ mass concentrations in China in previous study. In this study, the $\mathrm{PM}_{1}$ and $\mathrm{rBC}$ concentrations were $10-230 \mu \mathrm{g} \mathrm{m}^{-3}$ and 0.7-11 $\mu \mathrm{g} \mathrm{m}^{-3}$ in Beijing during the campaign period (17 to 30 November 2014), which was consistent with previous studies in other polluted regions in China (Table S2). The consistency indicated that the enhancement of the light absorption capability of BC-containing particles associated with air pollution not only occurred in Beijing but also might be observed in other polluted regions in China.

\section{References}

Andreae, M. O., Schmid, O., Yang, H., Chand, D., Zhen Yu, J., Zeng, L.-M., and Zhang, Y.-H.: Optical properties and chemical composition of the atmospheric aerosol in urban Guangzhou, China, Atmos. Environ., 42, 6335-6350, 2008.

Bond, T. C., and Bergstrom, R. W.: Light Absorption by Carbonaceous Particles: An Investigative Review, Aerosol Sci. Technol., 40, 27-67, 2006.

Cappa, C. D., Onasch, T. B., Massoli, P., Worsnop, D. R., Bates, T. S., Cross, E. S., Davidovits, P., Hakala, J., Hayden, K. L., Jobson, B. T., Kolesar, K. R., Lack, D. A., Lerner, B. M., Li, S.-M., Mellon, D., Nuaaman, I., Olfert, J. S., Petäjä, T., Quinn, P. K., Song, C., Subramanian, R., Williams, E. J., and Zaveri, R. A.: Radiative Absorption Enhancements Due to the Mixing State of Atmospheric Black Carbon, Science, 337, 1078-1081, 2012.

Chung, S. H., and Seinfeld, J. H.: Global distribution and climate forcing of carbonaceous aerosols, J. Geophys. Res.-Atmos., 107, AAC 14-11-AAC 14-33, 10.1029/2001JD001397, 2002.

Drinovec, L., Močnik, G., Zotter, P., Prévôt, A., Ruckstuhl, C., Coz, E., Rupakheti, M., Sciare, J., Müller, T., and Wiedensohler, A.: The" dual-spot" Aethalometer: an improved measurement of aerosol black carbon with real-time loading compensation, Atmos. Meas. Tech., 8, 1965-1979, 2015.

Gong, X., Zhang, C., Chen, H., Nizkorodov, S. A., Chen, J., and Yang, X.: Size distribution and mixing state of black carbon particles during a heavy air pollution episode in Shanghai, Atmos. Chem. Phys., 16, 5399-5411, 2016. 
1 Hänel, G.: The real part of the mean complex refractive index and the mean density of samples of atmospheric aerosol particles, Tellus, 20, 371-379, 1968.

Huang, X.-F., Xue, L., Tian, X.-D., Shao, W.-W., Sun, T.-L., Gong, Z.-H., Ju, W.-W., Jiang, B., Hu, M., and He, L.-Y.: Highly time-resolved carbonaceous aerosol characterization in Yangtze River Delta of China: Composition, mixing state and secondary formation, Atmos. Environ., 64, 200-207, 2013.

Hyvärinen, A.-P., Vakkari, V., Laakso, L., Hooda, R. K., Sharma, V. P., Panwar, T. S., Beukes, J. P., van Zyl, P. G., Josipovic, M., Garland, R. M., Andreae, M. O., Pöschl, U., and Petzold, A.: Correction for a measurement artifact of the Multi-Angle Absorption Photometer (MAAP) at high black carbon mass concentration levels, Atmos. Meas. Tech., 6, 81-90, 2013.

Kim, D., Wang, C., Ekman, A. M. L., Barth, M. C., and Rasch, P. J.: Distribution and direct radiative forcing of carbonaceous and sulfate aerosols in an interactive size-resolving aerosol-climate model, J. Geophys. Res.-Atmos., 113, 10.1029/2007JD009756, 2008.

Mallet, M., J.C. Roger, S. Despiau, O. Dubovik and J.P. Putaud (2003), Microphysical and optical properties of aerosol particles in urban zone during ESCOMPTE. Atmos. Res., 69(1-2), 73-97.

Marley, N.A., J.S. Gaffney, C. Baird, C.A. Blazer, P. J. Drayton and J. E. Frederick (2001), An empirical method for the determination of the complex refractive index of size fractionated atmospheric aerosols for radiative transfer calculations, Aerospace. Sci. Technol. 34(6), 535-549.

Schkolnik, G., D. Chand, A. Hoffer, M.O. Andreae, C. Erlick, E. Swietlicki and Y. Rudich (2007), Constraining the density and complex refractive index of elemental and organic carbon in biomass burning aerosol using optical and chemical measurements, Atmos. Environ., 41, 1107-1118.

Schulz, M., Textor, C., Kinne, S., Balkanski, Y., Bauer, S., Berntsen, T., Berglen, T., Boucher, O., Dentener, F., Guibert, S., Isaksen, I. S. A., Iversen, T., Koch, D., Kirkevåg, A., Liu, X., Montanaro, V., Myhre, G., Penner, J. E., Pitari, G., Reddy, S., Seland, Ø., Stier, P., and Takemura, T.: Radiative forcing by aerosols as derived from 
1 the AeroCom present-day and pre-industrial simulations, Atmos. Chem. Phys., 6, 5225-5246, 2006.

Segura, S., Estellés, V., Titos, G., Lyamani, H., Utrillas, M. P., Zotter, P., Prévôt, A. S. H., Mo`cnik, G., Alados-Arboledas, L., and Martínez-Lozano, J. A.: Determination and analysis of in situ spectral aerosol optical properties by a multi-instrumental approach, Atmos. Meas. Tech., 7, 2373-2387, 2014.

Taylor, J. W., Allan, J. D., Liu, D., Flynn, M., Weber, R., Zhang, X., Lefer, B. L., Grossberg, N., Flynn, J., and Coe, H.: Assessment of the sensitivity of core / shell parameters derived using the single-particle soot photometer to density and refractive index, Atmos. Meas. Tech., 8, 1701-1718, 2015.

Wang, Q., Huang, R. J., Cao, J., Han, Y., Wang, G., Li, G., Wang, Y., Dai, W., Zhang, R., and Zhou, Y.: Mixing State of Black Carbon Aerosol in a Heavily Polluted Urban Area of China: Implications for Light Absorption Enhancement, Aerosol Sci. Technol., 48, 689-697, 2014.

Weingartner, E., Saathoff, H., Schnaiter, M., Streit, N., Bitnar, B., and Baltensperger, U.: Absorption of light by soot particles: determination of the absorption coefficient by means of aethalometers, J. Aerosol Sci., 34, 1445-1463, 2003.

Zhang, G., Bi, X., He, J., Chen, D., Chan, L. Y., Xie, G., Wang, X., Sheng, G., Fu, J., and Zhou, Z.: Variation of secondary coatings associated with elemental carbon by single particle analysis, Atmos. Environ., 92, 162-170, 2014.

Zhang, H., Wang, Z., Wang, Z., Liu, Q., Gong, S., Zhang, X., Shen, Z., Lu, P., Wei, X., Che, H., and Li, L.: Simulation of direct radiative forcing of aerosols and their effects on East Asian climate using an interactive AGCM-aerosol coupled system, Clim. Dyn., 38, 1675-1693, 10.1007/s00382-011-1131-0, 2012.

Zhao, Q., Shen, G., Li, L., Chen, F., Qiao, Y., Li, C., Liu, Q., and Han, J.: Ambient Particles (PM10, PM2.5 and PM1.0) and PM2.5 Chemical Components in Western Yangtze River Delta (YRD): An Overview of Data from 1-year Online Continuous Monitoring at Nanjing, Aerosol Sci. Eng., 2017.

Zheng, G. J., Duan, F. K., Su, H., Ma, Y. L., Cheng, Y., Zheng, B., Zhang, Q., Huang, T., Kimoto, T., Chang, D., Pöschl, U., Cheng, Y. F., and He, K. B.: Exploring the 
1 severe winter haze in Beijing: the impact of synoptic weather, regional transport and

2 heterogeneous reactions, Atmos. Chem. Phys., 15, 2969-2983, 2015. 